This is an author-produced PDF of a 'research and policy' article accepted for publication in Arts \& Health: An International Journal for Research, Policy and Practice. The definitive publisher-authenticated version is available online at: DOI: 10.1080/17533015.2013.826259. Copyright Taylor \& Frances.

Complete citation information of that definitive version is: Grant, C. (2013). Participating in arts- and cultural-sector governance in Australia: Views and experiences of people with disability. Arts \& Health: An International Journal for Research, Policy and Practice. Doi: $10.1080 / 17533015.2013 .826259$

\title{
Participating in arts- and cultural- sector governance in Australia: Experiences and views of people with disability
}

\section{Catherine Grant}

\section{(Brisbane, Australia)}

\begin{abstract}
Background: This study sought the perceptions and experiences of people with disability relating to their potential or current involvement in the governance of arts and cultural organisations in Australia. Methods: Thirty-two people participated in an online survey, and results were analysed qualitatively and quantitatively. Results: The findings revealed that those participants who had been involved in governance benefited from it in terms of selfesteem, participation in society, and well-being. The results also indicated possible ways to encourage and enable more people with disability to become involved in governance roles, for example through the development of training and resources. Conclusions: This research represents a basis for future larger-scale studies relating to governance development for people with disability. Recommendations are made for future directions in both practice and research.
\end{abstract}

Keywords: disability, governance, well-being, arts and cultural organisations

\section{Background}

In a survey conducted in Britain in the mid-1990s, most respondents to a survey of 149 nonprofit charity organisations affirmed their belief that people with disability could cope with committee business (Drake, 1994). They also supported the notions that people with disability should have strong presence in governance, and a strong say in forming policy. But the reality differed. In voluntary organisations governed by people without disability in Drake's research (the significant majority of those surveyed), people with disability were largely absent in governance, almost totally excluded from paid employment, and generally experienced the same kinds of barriers within those organisations as they face in the wider world.

Drake (1996) suggests some causes of their exclusion, including that the "values, attitudes and beliefs of those who govern traditional charities accord largely with the 'personal tragedy' 
or medical model of disability" (p. 5), a perspective that confines people with disability to voluntary-sector roles in which they are unable to exercise much power. In Drake's research, the perceptions of people without disability towards people with disability include the belief that the latter "are not really capable of participating in the running of anything really" (p.7). Another barrier to participation in governance roles was the "hostile social environment", encompassing issues of access, communication, time, mobility, geography and isolation ( $\mathrm{p}$. 13). Physical and psychological factors, including the severity of a person's impairment, had a bearing upon the ability or desire of people with disability to become involved in governance (p. 15), as did relational factors, such as an anxiety that a person with disability would be viewed as representative of all people with disability (p. 14). Restricted access to decision-making tiers of governance, the alienating effects of jargon, and a lack of control over agenda setting may also play a role (Drake, 2002, p. 380).

Exclusion of people with disability in these ways is problematic. Good governance embraces and values diversity. Such diversity not only permits greater involvement of a range of people, but also benefits organisations by providing them a wider and more diverse skill set from which to draw in undertaking their various governance activities (Steane \& Christie, 2001, p. 49). A diversity of voices also provides different perspectives, which in turn can enhance the performance and creativity of a board (Panousieris, 2008, p. 91). This leads to a healthy and credible organisation that is able to take risks and embrace creativity (Radbourne, 2003 , p. 218). For these reasons, the participation of people with disability on boards of governance in arts and cultural organisations is one step towards good governance. It is therefore in the best interests of arts and cultural organisations, along with other stakeholders in the sector, to implement strategies to break down the potential barriers to participation in governance by people with disability.

Some significant advances in understanding and best practice have certainly occurred since the mid-1990s when Drake carried out his study, not only in terms of the value of diversity on boards of governance (e.g. Cochran Hadden, 2000; Drake, 2002, Panousieris, 2008), but also in terms of good governance practices generally (Conforth, 2003; Enjolras, 2009; Independent Sector, 2012; Steane, 2001; Steane \& Christie, 2001) and in the arts specifically (Klein, 1999; Nahkies, 2009; Radbourne, 2003; Roche \& Whitehead, 2005). The experiences and perspectives of individuals on participating in governance have also been explored to some extent, though largely through the voices of those already active in governance roles (e.g. Millesen \& Lakey, 1999, which evaluates how board members of US-based non-profit organisations viewed their roles, responsibilities, and commitment to the organisations they govern).

Despite these understandings, relatively little research on governance directly represents the perspectives and experiences of people with disability. Focusing on the arts and cultural sector in Australia, this study gathers, presents and analyses these perspectives. In so doing, it represents a small contribution towards two focus area goals of the National Arts and Disability Strategy (2009) in that country; namely, to "address the barriers which prevent emerging and professional artists and arts/cultural workers with disability from realising their ambitions", and to empower people with disability "to have a stronger voice in policy 
development and planning, and support informed decision making" (Cultural Ministers Council, 2009, p. 7). Given that the social equality, inclusion, and empowerment of people with disability remain worthwhile and necessary goals in the international context too, this study holds implications beyond the Australian context.

\section{Terminology}

Throughout this article, I adopt the broad definition of disability given in Australia's Disability Discrimination Act 1992 (Australian Human Rights Commission, 2012), which includes physical and sensory impairments, hidden impairments, learning disabilities and mental health conditions. My research is positioned within a social model of disability, an inclusive approach whereby disability is understood to be the result of barriers and negative attitudes that exist in society. This is in contrast with the medical model of disability, which by using the term to refer to medical conditions or impairments, arguably implies that any challenges associated with disability are the responsibility of the individual rather than society. In keeping with the social model of disability, and in line with the Arts Access Australia (2012) guidelines on language relating to disability, I use the term people with disability throughout the paper (in preference to terms like people with disabilities or disabled people). Although many people who are deaf identify as belonging to a cultural and linguistic minority, rather than as people with disability, my use of the term people with disability should be taken to include deaf people, since they too tend to experience barriers.

Following Nahkies (2009, p. 10), in this article I define governance as "the way in which a governing board fulfils its leadership and stewardship responsibilities by setting direction, policies, priorities, performance expectations and monitoring, and ensuring achievement consistent with these in order to exercise its accountability to key stakeholders." This definition places the governing board as primary agent in governance; Nahkies defines it as "...that part of the organisational architecture that has final responsibility for the performance of the organisation" (2009, p. 10). Within the Australian arts and cultural sector (as internationally), the governing board of an organisation may be known by various names, including board of directors, committee, and executive committee. Terms used for people who participate in such an entity also vary, and include director, board member, committee member, and management committee member. Note that many organisations have other elements that contribute to their governance, such as sub-committees, advisory boards, and so on; since these structures are part of the governance process too, they are taken into account in this research.

\section{Method}

\section{Aims}

This study was carried out as part of the wider research project Governance Development for Cultural Practitioners, Artists and Arts Administrators with Disability or who are Deaf. Funded by Arts Access Australia, the national peak body for arts and disability, that project investigated ways to increase the representation of cultural practitioners, artists and arts 
administrators with disability within the governance of arts and cultural organisations in Australia. In that context, the study reported on in this paper aims to answer the following question: What are the perceptions and experiences of cultural practitioners, artists and arts administrators with disability, as well as people with disability with experience in governance, in relation to participating in governance of arts and cultural organisations in Australia?

To this end, a survey was designed with the following objectives:

- To explore key perceptions and experiences of people with disability in relation to governance of arts and cultural organisations in Australia;

- To determine key barriers to participation in governance of people with disability; and

- To determine key strategies to enable or facilitate the participation in governance of people with disability.

The survey format was chosen for its capacity to generate both quantitative and qualitative data relating to the research topic, providing respondents opportunity to reflect more deeply on the issues if they wished (Bouma \& Ling, 2004, pp. 165-169). It also provided participants with options for how they gave input: they could fill out the survey in hardcopy or online formats (the latter using the survey tool Survey Monkey) or by phone, and were offered assistance from Access Arts Queensland to complete the survey. The survey instrument made clear that participation was voluntary and responses would be anonymous.

\section{Procedure}

Eligibility to participate in the survey was based on two criteria: (1) self-identification as a person with disability, or who is deaf or hard of hearing, with experience in a governance role; or (2) self-identification as an artist, cultural practitioner, and/or arts administrator (all openly defined, therefore potentially encompassing a wide range of roles within the arts and cultural sector) with disability, or who is deaf or hard of hearing. These criteria were stated on the first page of the survey instrument.

Arts Access Australia distributed an invitation to participate in the survey through its website and newsletter. In addition, two state-wide arts and disability organisations, Access Arts Queensland and Disability Arts Transition Team, South Australia, promoted the survey through their own networks, including through social media (Twitter).

At the close of the survey period, all survey responses were read through in their entirety, then compiled according to question, re-read and coded. Quantitative data for each question (where applicable) were entered into an Excel spreadsheet, which then formed the basis for tabulation of figures. Given the small sample size and the risk of making statistical inferences from these data, percentage calculations are not provided in the findings below. Qualitative data were analysed using an inductive approach, within a framework of five key issues addressed by the survey questions. This framework was developed in tandem with the design of the survey itself. These five issues are (1) involvement in governance; (2) factors enabling 
governance participation; (3) training, resources and support; (4) personal benefits of participating in governance; and (5) challenges and barriers to participation. Finally, responses were cross-referenced by question, including qualitative with quantitative data. Overall, these analysis procedures place emphasis on the meaning of responses, and position the researcher as an important factor in analysis, in the characteristic nature of qualitative research (Creswell, 2009).

\section{Survey Instrument}

The survey instrument comprised four sections. Section A provided respondents with information about the project and the survey itself, including eligibility to participate (see next section) and ethics-related information. Section B asked respondents about their current level of involvement in governance. Section $\mathrm{C}$ was only completed by those respondents currently active in a governance role, and related to their experience and perceptions of participating in governance. Section D asked respondents about their self-identification as an artist, cultural practitioner and/or arts administrator, and what their current status was in relation to working in the arts. The survey contained both open-response and closed-response (e.g. yes/no and Likert-style) questions.

To maximise the validity of the survey instrument, senior colleagues at Access Arts Queensland and Disability Arts Transition Team, South Australia joined me in reviewing the draft instrument for relevance of the questions, clarity in wording, use of standard English (taking into particular account disability language guidelines), absence of biased language, formatting of questions, and clarity of the instructions (Fowler, 2002). Minor revisions were made before disseminating the survey.

\section{Results}

Thirty-two respondents completed the survey (all of them online). The majority (23) identified as an artist; some also (non-exclusively) identified as a cultural practitioner or arts administrator. Six respondents identified as neither artist, cultural practitioner nor arts administrator. Assuming the eligibility criteria for survey participation were met, these respondents had experience in a governance role.

Key survey results are presented here according to the five-part thematic framework arising from the survey questions, as mentioned earlier. Qualitative responses are reproduced verbatim, with the exception of corrected spelling errors and appropriate capitalisation. Quantitative data broken down by question is provided in the Appendix.

\section{Involvement in governance}

Twelve of the 32 respondents had current involvement in a governance role. Of 11 respondents to the question of length of involvement, all had over a year's experience in governance. The most commonly-held role by these respondents was that of an office-bearer, with committee membership a close second. The majority (6) were nominated or invited by 
someone else to participate in governance; only two had put themselves forward or selfnominated.

The remaining 20 survey respondents had no current involvement in governance. Of those, only 6 were currently seeking to become involved in the governance of an arts or cultural organisation. Of the other 14 respondents who were not currently seeking involvement, the two equally most frequently ticked reasons were "I'm not interested / I don't have time" and "I don't really understand the requirements of being involved in governance". Other ticked answers included "opportunities are not accessible", "I don't really know how to go about getting involved"; and "I feel discriminated against". One respondent added the comment: "I don't know if I have the skills".

\section{Factors enabling governance participation}

Among the 12 participants currently involved in governance roles, the most frequent response to the question about what has helped or enabled them to participate in governance was an accessible meeting venue ( 5 respondents). The second most frequent response was that the organisation underwent disability awareness training. Other ticked responses (in order of frequency) included communication provided in accessible formats, financial support for participating in governance, resources relating to governance, alternative formats (e.g. online) for participation, and information about how others with disability have become involved in governance. Five respondents said that none of the eight listed options had assisted them to participate in a governance role.

Among those 20 participants who had no current involvement with governance, the most frequently ticked answers to the question of what would help or enable them "a lot" to participate in governance were: "financial support or incentive for participating", "disability awareness training for the arts organisation", and "resources for me, relating to governance, e.g. manuals / 'how-to' guides". Governance training opportunities and information about others with disability who were involved in governance were also highly rated. "Communication provided in alternative formats" was the response that the most respondents ticked wouldn't help them at all (10 respondents) (though 3 respondents ticked that this would help them a lot).

With regard to the issue of financial support or incentive for participating, it is noteworthy that only 9 of the 32 total survey respondents were employed in the arts or cultural sector in a paid capacity at the time of filling out the survey.

\section{Training, resources and support}

Of 12 respondents who currently held a governance role, the majority (7) stated that the organisation in question provided them with no general training or resources to help them in that role. The rest stated that they had received general training or resources such as the organisation's "Policy and Guidelines" and an "Induction and Induction Kit". One respondent commented: 
As I had previously served as a board member, but had no induction as such at the time, it was judged that I had enough information to carry out the role. I did, given my professional background, but this could be problematic for someone who did not have such a background. I would recommend a more thorough induction in most circumstances, of course taking into account the context which the nominee brings with them.

Of these same 12 respondents, the majority (7) of them stated that they had received no additional training, resources or support, as a person with disability. Of the remaining 5 who did receive specific training, resources, or support, one commented:

As an arts facilitator I receive excellent support from this organisation. To me this is in terms of excellent working conditions. I also receive professional development mentoring.

Two other respondents also raised the issue of mentoring, though had a less positive experience in this regard:

I was seen as a person with potential, but I was not provided officially with a mentoring relationship in which to explore my concerns, to learn and to develop more in-depth understanding. In that regard, and perhaps despite others' opinions, I have been a disappointment I feel in governance roles. I guess I must add that perhaps these governance roles could, as indicated in the questionnaire, have led to a more meaningful paid role than the one in which I am currently employed.

Probably what I have lacked is the personal relationships/mentoring experiences that could result in me being a better leader or contributor to governance. . . I would like to be involved particularly within a mentoring relationship as the mentee ...

\section{Personal benefits of governance participation}

When asked about the personal / individual outcomes from their participation in governance, 8 of the 12 survey respondents with governance experience ticked 'personal satisfaction'. Additionally, half or more of all respondents said that their participation in governance had resulted in an increased sense of worth / belonging / purpose, the opportunity to provide representation and a voice for people with disability, and increased self-confidence. Other responses included professional skill development, paid employment, and other responsibilities or engagements. Two respondents said that their participation in governance had resulted in none of these listed options.

Participants most frequently cited personal or individual benefits as the most positive thing about participating in governance, for example: "having a voice", "the sense of achievement against all odds"; "I like to know that even though I have an intellectual disability I can still have a voice within an organisation"; and "it helped me to talk to other people and respect people with a different aspect on life". Other respondents valued the possibility of "helping to shape and improve organisations" and "know[ing] about the processes involved in the provision of support for people who experience disability". 


\section{Challenges and barriers to governance participation}

Respondents with current governance experience provided insights into the least positive aspect of participating in governance, for them. Two referred directly to disability: "Some hearings excluded deaf people" and "I have to bring my disability to the fore sometimes when I feel I should not have to". The lack of mentorship within governance structures (mentioned above) was also raised here. A number of respondents referred to ineffective, inadequate, inconvenient, tokenistic or even hostile governance processes or procedures as the least positive aspect of their participation in governance:

Prejudice and rejection by disability organisations.

How people go over other people's head[s].

The limitations within systems for people to have their needs, wants and desires met at a most basic level.

Sometimes the meetings go very late and I am tired and hungry.

I think disabled and Deaf people end up sitting forever on committees and boards basically giving away their expertise for no reward. The organisation gets to tick the boxes re disability involvement without having to change a single thing about their workplace, workforce, practises and priorities.

I am on the board of an arts organisation which has no other members with disability so dealing with these issues is not within their culture.

Frustration with lack of governance expertise in small not for profits - too laid back an attitude - only acting when problems arise rather than being proactive. Too much reliance on good will instead of good governance.

\section{Discussion}

All data should be interpreted remembering that the respondents were sourced through the networks of arts and disability organisations in Australia, and therefore are not necessarily representative of people with disability more generally.

Given the scarcity of research on the views of the general population on participating in arts and cultural sector governance (in Australia or elsewhere), it is hard to determine the extent to which their views and experiences might align or contrast with those of the people with disability who responded to this survey. The barriers and enablers to governance participation revealed here may also hold true to some extent for people without disability; adopting a governance role is not unambiguously easy for anyone, and training and resources can surely help. Nearly half the 672 respondents to a survey of board members of US-based non-profit organisations, for example, were less than satisfied with new board member orientation; they believed that "a comprehensive board orientation and/or and ongoing training program" would help them learn relevant skills and become better board members (Milleson and 
Lakey, 1999, p. 10). Likewise, the individual benefits and challenges of participating in governance may be similar for people with and without disability. For instance, Our Community refers to 'making a difference', 'gaining new skills' and 'expanding networks' as being among the "highs" of governance participation (for people with or without disability) (n.d.(b)), reflecting the more specific findings of this current survey.

For these reasons, the following discussion should be understood in the context of evidence (albeit mostly anecdotal, as noted above) that people with disability are currently underrepresented in governance roles in arts and cultural organisations in Australia. Strategies to remove barriers, support participation, and empower and encourage involvement of this group are therefore important, regardless of similarities or differences with the experiences, views, and representation of the general population in governance participation. In time, further studies will hopefully improve understanding of these issues.

The finding that the majority of respondents in this study (20 of the 32) were not currently involved in a governance role, and the majority of those (14) were not seeking to become involved in one, may suggest a need for advocacy and awareness-raising for people with disability in relation to governance involvement. This potential need is corroborated by the statements of most survey respondents not seeking to become involved in governance: either they weren't interested/lacked the time, or lacked understanding of the requirements of governance involvement. Also, of all respondents with a current governance role, over half were nominated or invited by someone else. In designing strategies to encourage people with disability to become involved with governance, stakeholders might remember that increasing the supply of opportunities for participating in governance does not necessarily mean that more people with disability will participate, or that they will participate more frequently or deeply (cf. LeRoux, 2009, p. 514). Other strategies will be important, such as providing appropriate training and resources, discussed further below.

Respondents reported a range of challenges and downsides to their participation in governance. One of these was a frustration with organisations satisfying quotas ('ticking boxes') by involving people with disability in governance roles. Much literature cautions organisations against including people on governance committees to meet the requirements of funding bodies, to fulfil a quota, or for the sake of appearances (e.g. Drake, 1996; Cochran Hadden, 2005; Whitehead, 2005). Levels of engagement in governance can range from tokenism at one end to "extensive democratic power sharing and genuine collaboration" at the other (Drake, 2002, pp. 375-376). The survey results therefore suggest that arts and cultural organisations in Australia might critically reflect on the extent to which they truly share power and genuinely include people with disability in their governance processes. This is particularly important given the general imperative to empower people with disability (in the specific context of the Australian arts and disability strategy, but also within the social model of disability at large). Furthermore, equitable power-sharing stands to benefit these organisations themselves, since this is one of the identified hallmarks of good governance.

Other challenges or barriers to governance involvement raised by survey respondents included practicalities (e.g. meetings that go very late) through to issues of 'prejudice and 
rejection', exclusion, lack of mentorship, frustration with the processes and procedures of governance itself, and the organisation's lack of a 'culture' of dealing with disability-related issues. Some or all of these issues might be addressed through disability awareness training for the arts organisation, an undertaking that was considered important by respondents not currently involved in governance, as a means for enabling or facilitating their participation in governance. Those respondents who were currently active in governance roles corroborated the importance of disability awareness training for organisations, a third of them stating that such training had assisted their participation in those roles.

The call for disability awareness training for organisations is by no means new (internationally, it dates back to at least the 1980s, when the Attenborough report on "arts and disabled" people" was released; Attenborough \& Carnegie United Kingdom Trust, 1985), but the need for it, and for ongoing evaluation of its purposes and outcomes, is ongoing. Training and resources for the arts sector might educate organisations on the equality of people with and without disability (especially given survey responses relating to prejudice and exclusion), and promote understanding of the social model of disability, whereby the responsibility for creating an inclusive environment is shared. They might alert organisations to various forms of direct or indirect discrimination that might prevent people with disability from participating in the governance of an organisation, such as insisting on in-person attendance to board meetings, or not providing sufficient or accessible induction into governance roles. Training and resources might also highlight the need for clear descriptions of the terms and conditions of the governance role, as well as suggest ways to implement physical or organisational changes to enable a person with disability to be appointed to a governance role, undertake relevant training, and so on. Some of these issues are usefully discussed by Gration (1998) (though with reference to removing barriers to participation by people with disability in arts events, rather than in the organisational structure). Whitehead reminds organisations that:

Successfully including a more diverse group of people means the board itself has to change; it has to include a broader range of ideas and be attuned to a wider range of voices. It is a two-way process; the new board members and the old board members learn from each other. (2005, pp. 283-284)

While respondents also strongly indicated financial support or incentive would help or enable them to participate in governance roles, only two respondents currently in governance roles reported receiving financial recompense. This is in line with the findings of a recent survey of Australasian non-profit boards, which revealed that $85 \%$ of the 220 participating organisations did not remunerate their board members (Better Boards Australasia, 2011). Enjolras suggests that involvement in the governance of voluntary organisations is likely to be motivated by intrinsic and value-orientated incentives like pleasure and personal satisfaction, rather than extrinsic motivations like money (2009, p. 776). The survey findings confirm that participating in governance brought respondents individual and social benefit, including personal satisfaction, an increased sense of worth / belonging / purpose, increased self-confidence, and the opportunity to provide representation and a voice for people with disability. For several respondents, the 'most positive thing' about participating in 
governance was framed in these terms of achievement, purpose, and well-being. Involvement in governance has been shown to enhance sense of civic participation, as well as building knowledge and skills that may then be transferred to other areas of participation in society (e.g. LeRoux, 2009, p. 503).

Respondents indicated that resources and training for people with disability would facilitate their participation in governance, such as manuals and 'how-to' guides, information on other people with disability involved in governance, and governance training opportunities. Strikingly, more than half the respondents with a current governance role stated that they had received no general training or resources, nor training or resources specific to their needs as a person with disability, to help them in their governance role. Training need not be formal; the survey responses indicate that its participants place high value on mentoring, for example, as an enabler to governance participation. With potential benefits for mentor and mentee, as well as whole-of-organisation dividends in terms of fostering a supportive culture of reflective practice, mentoring seems a promising avenue for further exploration.

Resources, training and mentoring for people with disability could cover topics such as appointment processes, duties and responsibilities, meeting procedures, legal issues, understanding organisational finances and accounting, and dealing with constitutions (Panousieris, 2008, p. 92). In terms of existing resources, two examples are the "how-to books" housed on the online Boards, Committees \& Governance Centre (an Australian site), which guide individuals to secure and successfully carry out a position on the board of a community organisation; and the series of help-sheets on the same site, designed for people who are new to governance roles, to "step you through all of the things you need to know and do in order to prepare for a new board role" (Our Community, n.d.(a)). Another is The Artist Resource, "an online platform for artists to access professional development information, networks and pathways" (Accessible Arts, 2012). Although these are highly useful resources, they are not directed specifically towards people with disability seeking participation in governance.

Training specifically for people with disability, and specifically in relation to participation in governance, does not yet exist in Australia. Various organisations offer formal or semi-formal training in governance, including the Australian Institute for Community Practice and Governance, which provides local practical, accredited (non-disability-specific) governance training for board / committee members (AICPG, n.d.), and Leadership Plus, a community organisation "that promotes people with disabilities as leaders" in society and the workplace (Leadership Plus, 2011). Promisingly, the recent Better Boards Non-Profit Board Member Remuneration Survey revealed that $70 \%$ of the 220 Australasian non-profit organisations surveyed recognised the value of ongoing professional development for board members by paying associated costs (Better Boards Australasia, 2011, 'Key Findings' section). Relevant, appropriate training empowers people to effectively and meaningfully participate in governance roles (Panousieris, 2008, p. 92). 
The earlier-mentioned research project Governance Development for Cultural Practitioners, Artists and Arts Administrators with Disability or who are Deaf aims to address, in the Australian context at least, some of the gaps in resources and training revealed through this study. Intended outcomes include case studies of board participation by people with disability, and recommendations for developing further targeted training for individuals and organisations. Resources are planned in the form of "how-to" guides, both for people with disability interested in joining arts or cultural boards of governance, and for arts- and cultural- sector organisations looking to increase the representation of people with disability on their boards.

The research reported on in this paper is one small step in a chain that works to remove the social and physical barriers that prevent people with disability from fully participating in the governance of arts and cultural organisations in Australia and beyond. Further studies may seek to corroborate the findings of this study, both by conducting similar research on a larger scale (with more respondents) and in other contexts (in other countries, and internationally). Specifically, and among other things, they may aim to identify similarities and divergences in perspectives on cultural-sector governance between people with disability and those without; investigate good practice models for organisational training and resource development; further explore ways to empower people with disability to participate in governance roles; and examine in greater depth the individual and organisational benefits of governance participation by people with disability. Outcomes of such research may act as advocacy tools for increasing participation of people with disability in governance, and may also assist arts and cultural organisations to understand their responsibilities and potential to engage people with disability in governance roles. In these ways, it is hoped this project will eventually lead to better governance practice in the arts, while also giving voice to those cultural practitioners, artists, and arts administrators with disability who make a fundamental contribution to the vitality of the arts and cultural sectors at large.

\section{Acknowledgments}

This article is an outcome of research conducted in 2012, in my role as contracted research assistant for the project Governance Development for Cultural Practitioners, Artists and Arts Administrators with Disability or who are Deaf. The project, a collaboration between Access Arts Queensland and Disability Arts Transition Team, South Australia, was funded by Arts Access Australia. My thanks to Access Arts Queensland and the anonymous reviewers, who provided helpful critical feedback on an earlier version of this article.

\section{Author biography}

Catherine Grant is Research Fellow at Queensland Conservatorium Research Centre, Griffith University, and a board member of Multicultural Centre for Mental Health and Wellbeing (Harmony Place).Catherine.grant@griffith.edu.au 
Appendix

This appendix contains key quantitative data from the survey. Percentages are rounded to the nearest whole figure.

Table 1. Self-identification of participants in relation to the arts

I am...

an artist

a cultural practitioner

an arts administrator

none of the above

$\begin{array}{cc}\begin{array}{c}\text { Response } \\ \text { Percent }\end{array} & \begin{array}{c}\text { Response } \\ \text { Count }\end{array} \\ 72 \% & 23 \\ 25 \% & 8 \\ 28 \% & 9 \\ 19 \% & 6\end{array}$

answered question

skipped question

Table 2. Current employment in the arts or cultural sector

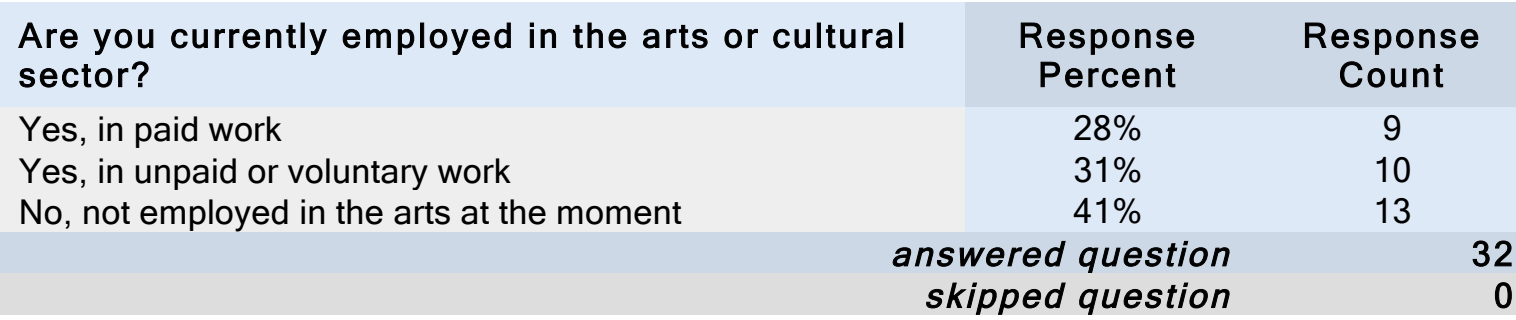

Table 3. Current involvement in governance

Are you currently involved in the governance of an organisation?

Yes, an arts/cultural organisation

Yes, but not an arts/cultural organisation No
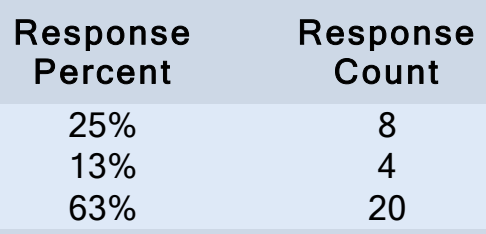

answered question

skipped question

Table 4. Currently seeking involvement in governance of an arts/cultural organisation

\begin{tabular}{|c|c|c|}
\hline $\begin{array}{l}\text { Are you currently seeking involvement in } \\
\text { governance of an arts/cultural organisation? }\end{array}$ & $\begin{array}{l}\text { Response } \\
\text { Percent }\end{array}$ & $\begin{array}{l}\text { Response } \\
\text { Count }\end{array}$ \\
\hline $\begin{array}{l}\text { Yes } \\
\text { No }\end{array}$ & $\begin{array}{l}30 \% \\
70 \%\end{array}$ & $\begin{array}{c}6 \\
14\end{array}$ \\
\hline & $\begin{array}{l}\text { red question } \\
\text { ped question }\end{array}$ & $\begin{array}{l}2 \\
1\end{array}$ \\
\hline
\end{tabular}

Table 5. Reasons for not currently seeking participation in governance 
Reasons for not seeking participation

I'm not interested / I don't have time

I don't know how to go about getting involved

I don't really understanding the requirements of being

involved in governance

Opportunities are not accessible

I feel discriminated against

Other (please specify)

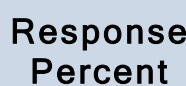

$35.7 \%$

$14.3 \%$

$35.7 \%$

$14.3 \%$

$14.3 \%$

$21.4 \%$

answered question

skipped question
Response Count

5

2

5

2

2

3
14

18

Table 6. Perceptions of what would enable participation in cultural-sector governance

To what degree would each of the following help or enable you to participate in the governance of an arts or cultural organisation? Alternative formats for participation in governance (e.g. online)

Communication provided in alternative formats

Disability awareness training for the arts organisation

Training opportunities for me, relating to governance

Resources for me, relating to governance (e.g. manuals / 'how-to' guides)

disability have become involved in

governance

Financial support or incentive for participating
Accessible venue for meetings

Information about how others with a

$\begin{array}{cccc}\begin{array}{c}\text { Wouldn't } \\ \text { help me } \\ \text { at all }\end{array} & \begin{array}{c}\text { Would } \\ \text { help me a } \\ \text { little }\end{array} & \begin{array}{c}\text { Would } \\ \text { help me a } \\ \text { lot }\end{array} & \begin{array}{c}\text { Response } \\ \text { Count }\end{array} \\ 6 & 6 & 7 & 19 \\ 10 & 5 & 3 & 18 \\ 6 & 6 & 6 & 18 \\ 2 & 6 & 11 & 19 \\ 4 & 5 & 9 & 18 \\ 3 & 6 & 10 & 19 \\ 2 & 8 & 9 & 19 \\ 3 & 5 & 12 & 20 \\ & \begin{array}{l}5 \\ \text { answered question } \\ \text { skipped question }\end{array} & 12\end{array}$

Note: Only those 12 people with disability who had identified as having current governance experience were able to access the survey questions that yielded the data in the remainder of this Appendix. Not all questions received a $100 \%$ response rate.

Table 7. Length of involvement in governance

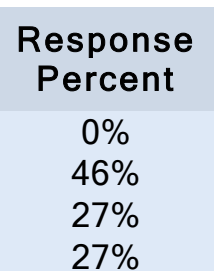

answered question

skipped question

Table 8. Governance role 


\begin{tabular}{|c|c|c|}
\hline What is your governance role? (Tick all that apply) & $\begin{array}{c}\text { Response } \\
\text { Percent }\end{array}$ & $\begin{array}{c}\text { Response } \\
\text { Count }\end{array}$ \\
\hline Office-bearer (e.g. president, treasurer, secretary) & $46 \%$ & 5 \\
\hline Committee member & $36 \%$ & 4 \\
\hline Sub-committee member & $9 \%$ & 1 \\
\hline \multirow{2}{*}{ Other (please specify) } & $27 \%$ & 3 \\
\hline & $\begin{array}{l}\text { red questio } \\
\text { ped questio }\end{array}$ & \\
\hline
\end{tabular}

Table 9. Means of acquiring governance role

How did you get this role?

$\begin{array}{cc}\begin{array}{c}\text { Response } \\ \text { Percent }\end{array} & \begin{array}{c}\text { Response } \\ \text { Count }\end{array} \\ 55 \% & 6 \\ 18 \% & 2 \\ 27 \% & 3\end{array}$

Someone else invited or nominated me

I put myself forward or self-nominated

Other (please specify)

Table 10. Provision of governance training and resources

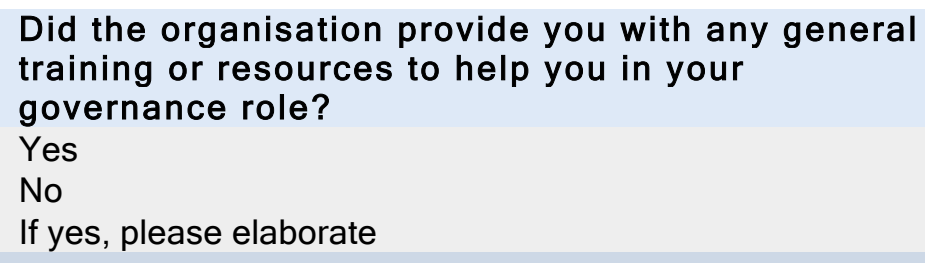

If yes, please elaborate

$\begin{array}{cc}\begin{array}{c}\text { Response } \\ \text { Percent }\end{array} & \begin{array}{c}\text { Response } \\ \text { Count }\end{array} \\ 42 \% & 5 \\ 58 \% & 7 \\ & 4\end{array}$

Table 11. Provision of disability-specific governance training and resources

As a person with disability, did the organisation provide you with any additional training, resources or support to help you undertake your governance role?

Yes

Response Response

Percent Count

No

$42 \% \quad 5$

$58 \% \quad 7$

If yes, please elaborate

7

Table 12. Perceptions of what has assisted participation in governance

Which of the following has assisted you to participate in governance? (Tick all that apply)

I was provided with alternative formats for participation in governance (e.g. online)

Communications were provided in accessible formats

The meeting venue was accessible

The organisation underwent disability awareness training

$\begin{array}{cc}\begin{array}{c}\text { Response } \\ \text { Percent }\end{array} & \begin{array}{c}\text { Response } \\ \text { Count }\end{array} \\ 17 \% & 2 \\ 25 \% & 3 \\ 42 \% & 5 \\ 33 \% & 4\end{array}$


I was given training relating to governance

I was provided with resources relating to governance (e.g.

manual / 'how-to' guide)

I was provided information about how others with disability

have become involved in governance

I was given financial support or incentive for participating in

governance

None of the above

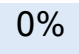

$17 \%$

$8 \%$

$17 \%$

$42 \%$

$0 \%$

answered question

skipped question

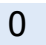

2

1

2

5

0

Table 13. Personal outcomes of governance participation

$\begin{array}{lcc}\begin{array}{l}\text { Has your participation in governance resulted in } \\ \text { any of the following? (Tick all that apply) }\end{array} & \begin{array}{c}\text { Response } \\ \text { Percent }\end{array} & \begin{array}{c}\text { Response } \\ \text { Count }\end{array} \\ \text { Personal satisfaction } & 67 \% & 8 \\ \text { Increased sense of worth / belonging / purpose } & 58 \% & 7 \\ \text { Increased self-confidence } & 50 \% & 6 \\ \text { Professional skill development } & 33 \% & 4 \\ \text { Opportunity to provide representation and a voice for people } & 50 \% & 6 \\ \text { with disability } & 33 \% & 4 \\ \text { Other responsibilities or engagements } & 17 \% & 2 \\ \text { Paid employment } & 17 \% & 2 \\ \text { None of the above } & 8 \% & 1 \\ \text { Other (please specify) } & \text { answered question } & \\ & \text { skipped question } & \\ & & \end{array}$

\section{References}

Accessible Arts (2012). Artist resource. Retrieved 20 May, 2012, from http://www.aarts.net.au/resources/artist-resource/

Arts Access Australia (2012). AAA advice on disability language. Retrieved 27 October, 2012, from http://www.artsaccessaustralia.org/resources/advice-sheets/63-aaa-advice-on-disabilitylanguage

Attenborough, R. \& Carnegie United Kingdom Trust (1985). Arts and disabled people: Report of a committee of inquiry under the chairmanship of Sir Richard Attenborough. London: Bedford Square Press.

Australian Human Rights Commission (2012). Disability Discrimination Act 1992. Retrieved 23 November, 2012, from http://humanrights.gov.au/disability rights/

Australian Institute of Community Practice and Governance (n.d.). Website. Retrieved 19 July, 2012, from https://www.ourcommunity.com.au/training/training main.jsp

Better Boards Australasia (2011). Better Boards non-profit board member remuneration survey:

Executive summary. Retrieved 10 July, 2012, from

http://betterboards.net/betterboardsnews/board-member-remuneration-survey-executivesummary/.

Bouma, G. D. \& Ling, R. (2004). The research process $\left(5^{\text {th }}\right.$ ed.). Melbourne: Oxford University Press. 
Cochran Hadden, G. (2000, July). Directing diversity. Centrepiece. Retrieved 9 July, 2012, from http://www.tcg.org/pdfs/publications/centerpiece/centerpiece 0700.pdf

Cochran Hadden, G. (2005). The spirit of governance: Six interviews [interview 2]. In Roche, Nancy $\&$ Whitehead, Jann (Eds.). The art of governance: Boards in the performing arts, 109113. New York: Theatre Communications Group.

Cornforth, C. (Ed.) (2003). The governance of public and non-profit organisations: What do boards do? London \& New York: Routledge.

Creswell, J. (2009). Research design: Qualitative, quantitative and mixed-methods approaches ( $3^{\text {rd }}$ ed.). Thousand Oaks, CA: Sage.

Cultural Ministers Council (2009). National arts and disability strategy. Retrieved 10 July, 2012, from http://www.cmc.gov.au/working groups/national arts and disability strategy

Drake, R. F. (1994). The exclusion of disabled people from positions of power in British voluntary organisations. Disability \& Society 9(4), 461-480. Retrieved 24 June, 2012, from Taylor \& Francis Online.

Drake, R. F. (1996). Charities, authority and disabled people: A qualitative study. Disability \& Society 11(1), 5-24. Retrieved 24 June, 2012, from Taylor \& Francis Online.

Drake, R. F. (2002). Disabled people, voluntary organisations and participation in policy making. Policy \& Politics, 30(3), 373-385.

Enjolras, B. (2009). A governance-structure approach to voluntary organizations. Nonprofit and Voluntary Sector Quarterly 38(5), 761-783.

Fowler, F. J. (2002). Survey research methods ( $3^{\text {rd }}$ ed.). Thousand Oaks, CA: Sage.

Gration, N. (1998). Disability fact pack. DADAA National Network and the Australia Council. Retrieved 20 May, 2012, from http://www.australiacouncil.gov.au/resources/reports and publications/subjects/arts and disa bility/disability_fact_pack

Independent Sector (2012). Resource Centre for Good Governance and Ethical Practice. Retrieved 19 July, 2012, from http://www.independentsector.org/governance ethics resource center

Klein, S. (1999). The art of serving on a performing arts board. Theatre Bay Area and National Centre for Nonprofit Boards.

Leadership Plus (2011). Leadership Plus: Disability and social change. Retrieved 19 July, 2012, from http://www.leadershipplus.com/

LeRoux, K. (2009). Paternalistic or participatory governance? Examining opportunities for client participation in nonprofit social service organizations. Public Administration Review 69(3), 504-517. Retrieved 25 June, 2012, from Proquest database.

Millesen, J. \& Lakey, B. (1999). The nonprofit board self-assessment process: Lessons from the field. Washington DC: BoardSource. Retrieved 19 March, 2013, from http://www.boardsource.org/dl.asp?document id=22

Nahkies, G. (2009). Getting on board: A governance resource guide for arts organisations $\left(3^{\text {rd }}\right.$ ed.). Wellington: Creative New Zealand. Retrieved 6 July, 2012, from 
http://www.creativenz.govt.nz/assets/paperclip/publications/files/33/original/getting-onboard.pdf?1300394226

Our Community (n.d.(a)). Boards, Committees \& Governance Centre. Retrieved 10 July, 2012, from http://www.ourcommunity.com.au/boards/boards_main.jsp

Our Community (n.d.(b)). Boards: What's in it for me? Retrieved 21 March, 2013, from http://www.ourcommunity.com.au/boards/boards_helpsheet.jsp?articleld=1320

Panousieris, G. (2008). Governance and diversity: Encouraging and enabling participation from marginalised and minority community groups. Just Policy: A Journal of Australian Social Policy 49, 90-93. Retrieved 25 June, 2012, from Informit database.

Radbourne, J. (2003). Performing on boards: The link between governance and corporate reputation in nonprofit arts boards. Corporate Reputation Review 6(3), 212-222. $\mathrm{http} / / /$ search.proquest.com.libraryproxy.griffith.edu.au/docview/231529287?accountid=14543

Roche, N. \& Whitehead, J. (Eds.) (2005). The art of governance: Boards in the performing arts. New York: Theatre Communications Group.

Steane, P. (2001). Governance: Convergent expectations, divergent practices. Corporate Governance 1(3), 15-19. doi: 10.1108/EUM0000000005490

Steane, P. \& Christie, M. (2001). Nonprofit boards in Australia: A distinctive governance approach. Corporate Governance: An International Review, 9: 48-58. doi: 10.1111/1467-8683.00225.

Whitehead, J. (2005). Additional perspectives: Small theatres, artists trustees and alternative models. In Roche, Nancy \& Whitehead, Jann (Eds.). The art of governance: Boards in the performing arts, 269-291. New York: Theatre Communications Group. 